\title{
Impact of Products, Promotion and after Sale Services on Satisfaction of PTCL's (Pakistan Telecommunication Company Ltd.) Customers
}

Ahmad Nawaz*

Department of Life Sciences, University of Central Punjab, Lahore, Punjab, Pakistan

\begin{abstract}
Our study's objective is to check the two casual relationships, the first relationship between Products and Promotions and Customer Satisfaction of PTCL's Customers. The second causal relationship between after sale services and customer satisfaction of PTCL's customers.
\end{abstract}

Keywords: PTCL; Public organization; Customer satisfaction; Promotional strategies

\section{Introduction}

Promotion is utilized by companies to speak with clients as for their item offerings. In this sense, Promotion is one side of the correspondence procedure with clients. Statistical surveying, in which providers look to evoke data on purchaser prerequisites from customers, is the integral segment of the correspondence procedure. As industries and firms worldwide face increasing competition, slower growth rates, and price pressures, greater attention is being placed on customer satisfaction. Satisfaction is an important determinant of customer retention which, in turn, has a very strong effect on profitability Consumer satisfaction has been extensively studied in marketing over the last few decades. However, marketing scholars have not yet agreed upon a generally accepted definition of satisfaction. The term, "after-sales services" is used, to describe services that are provided to the customer after the products have been delivered [1]. The same services are sometimes being also called "field services", when they are embodied in the main characteristics that are located at a customer's site [2]. "After-sales support" [2] as well as "technical support" or even just "services", are terms also found in the literature [3]. The research problem is that Customer bank of PTCL is being affected by the other telecommunication companies (Zong, Telenor, Warid, and Jazz) after the launch of $3 \mathrm{G}$ and $4 \mathrm{G}$ in Pakistan few years ago. Before the privatization of PTCL, people were complaining about the dealings of PTCL. This study will analyze, is there still same situation or has been changed? Our study's objective is to check the two casual relationships, the first relationship between Products and Promotions and Customer Satisfaction of PTCL's Customers. The second causal relationship between After Sale Services and Customer Satisfaction of PTCL's Customers. Our research question is as follow; "What is the Impact of Products and Promotion and After Sale Services on Satisfaction of PTCL's Customers?" The scope or audience of this research paper is the customers of PTCL including old and current customers. This study is for the Management of PTCL, it would be helpful for them to achieve more customers bank by developing new strategies and offering new services to their customers. This study will be helpful for the management of PTCL, to formulate new strategies to gain new customers and retain the existing customers for the longer period of time. This study will enable the management to understand the drawbacks of their services and strategies and put their consideration on this side. This study will also make its contributions to the literature of Customer Satisfaction, After Sales Services. And this would be beneficial for the Marketers of other organizations in the economy of the Pakistan.

\section{Research Methodology}

The sequence of the study is as follow, first there is history of PTCL Company which is a part of introduction chapter. In the second chapter reviewed the same important past studies on these three variables including independent variables and dependent variable, proposed two hypotheses. In third chapter, we have discussed methodology used for this study, in the fourth chapter we presented statistical findings including both descriptive analysis and inferential analysis. Then in the next chapter we have discussion based on our results, then we concluded this paper with some limitations and future directions for the further studies.

\section{History of Company}

Today, the telecommunications industry is exposed to fierce competition. National and geographical borders no longer coincide with those of telecommunications. The same products and services are developed and offered in a number of different countries. Since, the invention of telephone as a medium of communication, the telecommunication has been growing byleaps and bounds. Competition among different firms has led to creative and innovative solutions regarding the usage of phones all over the world. Mobile phones are one such creation, in this regard, that had taken the telecommunication industry to new heights.

Since the independence of Pakistan, basic telecom services were being provided by a monopolist, previously called as Telephone and Telegraph department (T\&T). The department was being run by the government and played multiple roles as regulator, policy maker, operator and service provider in the country. The T\&T department was later converted into a corporation. Although the corporation was earning huge profits from the services, it was re-investing the same profits into the sector for the provision of more telecom service, but the investment was not enough. Further, with the technological advancement, more and more telecom services were becoming available but there was not enough money available with the corporation to

*Corresponding author: Ahmad Nawaz, Department of Life Sciences, University of Central Punjab, Lahore, Punjab, Pakistan, Tel: + 923157635165, E-mail: ahmad.nawaz1992@ucp.edu.pk

Received April 21, 2018; Accepted April 24, 2018; Published April 30, 2018

Citation: Nawaz A (2018) Impact of Products, Promotion and after Sale Services on Satisfaction of PTCL's (Pakistan Telecommunication Company Ltd.) Customers. Review Pub Administration Manag 6: 244. doi:10.4172/2315-7844.1000244

Copyright: (c) 2018 Nawaz A. This is an open-access article distributed under the terms of the Creative Commons Attribution License, which permits unrestricted use, distribution, and reproduction in any medium, provided the original author and source are credited. 
install new telecom systems for the provision of modern services. Resultantly, a digital divide prevailed in Pakistan keeping it behind its neighbors and other comparable countries in terms of telecom access. The Telecom Sector has contributed 2 percent towards the overall GDP growth with revenues of over PKR 235bn.

With employee strength of 35,000 and 5.7 million customers, PTCL is the largest telecommunications provider in Pakistan. PTCL also continues to be the largest CDMA operator in the country with 1.1 million V-Fone customers. Pakistan Telecommunication Company Limited (PTCL) is proud to be Pakistan's most reliable and largest converged services carrier providing all telecommunications services from basic voice telephony to data, internet, video-conferencing and carrier services to consumers and businesses all over the country. Telecommunication (Re-Organization) Act 1996, the basic telephony was put under exclusivity and PTCL was given a seven years' monopoly over basic telephony which ended by December 31, 2002. The year 2006-07 in the telecom sector witnessed a phenomenal growth in the mobile phone sector in Pakistan, which doubled its subscriber base to 60 million. The Tele density increased from $26 \%$ to $40 \%$, helping to spread the benefits of communication technology across the country.

\section{Customer satisfaction}

As industries and firms worldwide face increasing competition, slower growth rates, and price pressures, greater attention is being placed on customer satisfaction. Satisfaction is an important determinant of customer retention which, in turn, has a very strong effect on profitability Consumer satisfaction has been extensively studied in marketing over the last few decades. However, marketing scholars have not yet agreed upon a generally accepted definition of satisfaction.

Giese and Cote [4] after conducting a review of literature and consumer interviews, defined satisfaction as a summary affective response of varying intensity with a specific time point of determination and limited duration directed toward focal aspects of product acquisition and/or consumption. Consumer's satisfaction has been considered one of the most important constructs [5,6] and one of the main goals in marketing [7]. Satisfaction plays a central role in marketing because it is a good predictor of purchase behavior (repurchase, purchase intentions, brand choice and switching behavior) [6].

\section{After sales services}

Service has been rightly treated as one reliable vehicle for gaining sustainable competitive advantage, which means that service quality aspects possess a substantial strategic role for companies. This does not happen only in the pure service sectors, but also in many others where service is a considerable part of the augmented product. Indeed, the concept of "service quality" can be used to all sectors, since practically everywhere the total product-offering is a mixture comprised by a tangible and an intangible part.

The term, "after-sales services" is used, to describe services that are provided to the customer after the products have been delivered [1]. The same services are sometimes being also called "field services", when they are embodied in the main characteristics that are located at a customer's site [2]. "After-sales support" [2] as well as "technical support" or even just "services", are terms also found in the literature [3].

"After-sales services" are often referred to as "product support activities", by Lele and Karmarkar [8] meaning all activities that support the product-centric transaction. They are also found in the literature as "customer support" elements, meaning all activities that ensure that a product is available to consumers "over its useful lifespan for trouble-free use" [9]. Furthermore, the term "after-sales services" has been approached in the literature under two broad perspectives. When referring to service providing companies, after-sales services are being treated as one among several supplementary service elements provided by them [10]. On the other hand, when referring to tangible goods, they are mostly seen as operative activities of some or all members of the distribution chain [11]. Such services are the transport/delivery to clients, the installation, the product-related training, the hot line and advice by the help desk, any repairing service and even the recycling process.

The positive perceptions and attitudes of the target customers towards the quality-elements offered by the firm, leads to both attraction of new customers thanks to word-of-mouth (WOM) communication and recommendations of the existing customers, as well as to enhancement of the relationship of the company with its current customers by making them more loyal and committed. In other words, when referring to overall service quality perceptions, it is noticed that a substantial body of the literature [12] is in line with Zeithaml et al. [13] findings, claiming that overall service quality perceptions influence WOM communication, recommendations, as well as Loyalty. In this context, customer satisfaction has been the subject of a substantial body of literature [14] because of its influence on customer behavioral intentions and attitudes $[15,16]$. Regarding behavioral intentions, Zeithaml et al. [13] suggest that favorable behavioral intentions are mostly in the form of customers' referrals and recommendations, customers' willingness for re-purchasing as well as customers' willingness to spend more money with the particular company or to pay more for the products of this company.

On the ground of the above literature we proposed the following hypothesis:

Hypothesis 1: After - Sales Services are positively correlated to the customer satisfaction

\section{Product and promotion}

Firms often attempt to establish favorable, unique, and strong associations with a product through messages to consumers [17]. Consumer's affective and cognitive reactions to these messages presumably determine the relation between ad evaluations and brand evaluations. Brand beliefs [18] and feelings $[19,20]$ are formed through advertising. These beliefs affect attitudes toward ads and consequently attitudes toward the brands being advertised. Mackenzie et al., [21] compared four theoretical models of advertising and showed that attitudes toward ads have direct effects on brand attitudes and subsequently on purchase intentions.

Brand attitudes can be influenced in part by the corporate image of the advertiser. Corporate image is defined as evaluations, feelings, and attitudes toward a company $[22,23]$ or the associations and meaning a person has about a firm [17]. Corporate image can affect advertisers' reputation and corporate credibility [24] leading to beliefs about advertisers that consequently influence brand beliefs and attitudes $[18,25]$.

Promotion is utilized by companies to speak with clients as for their item offerings. In this sense, Promotion is one side of the correspondence procedure with clients. Statistical surveying, in which providers look to evoke data on purchaser prerequisites from customers, is the integral segment of the correspondence procedure. The following summarizes this very simply (Figure 1). 
In a few types of promotion and service conveyance, correspondence in both headings can be accomplished at the same time, and since two-way correspondence is the main genuine type of correspondence, promotion which is related with two-way correspondence is to be empowered [26]. Cases of such two-way advancement rise to a great extent from the settings of services marketing and relationship marketing. In service advertising, for instance, promotion can be a piece of the service conveyance.

An important question arises here, why is it rational for the suppliers/manufacturers and retailers to offer Promotion? To answer this question, Blattberg and Neslin [27] offer a concise categorization of the economic explanations that have been proposed in the literature. They added to this, "One set of arguments is based on differential costs of search and information processing, inventory-carrying, and time, across consumers." Another researcher said that there would be a way to "two-price" equilibrium if there are different search costs and ability to process information by the customers [28]. Blattberg, Eppen and Lieberman [29] added to the literature as "Promotions allow a retailer to shift the cost of carrying inventory to those consumers who have lower inventory holding costs and will therefore forward buy"

Promotional component is one of the key 4Ps in the marketing mix [30] and all things considered has a Key part to play in market achievement. Promotion is worried with guaranteeing that clients know about the items that the firm makes accessible to those clients. All the more specifically, the goals of any limited time technique will be drawn from a suitable mix of the accompanying parts of promotion; to: increment deals; keep up or enhance piece of the overall industry; make or enhance mark acknowledgment; make an ideal atmosphere for future deals; advise and instruct the market; make an upper hand, in respect to contender's items or market position; and enhance special efficiency [31].

In addition to this, promotion includes extensive speculation. It can as often as possible be difficult to separate between the impact of promotion and alternate components of the marketing mix [32]. Nevertheless, it is vital to screen the impacts of advancement, by taking a gander at deals figures and any measures of notoriety that are accessible. It is not compulsory to increase customer satisfaction by introducing new services or making new promotion strategies, sometimes it cause in huge losses both in financial and social.

On the ground of the above literature we proposed the following hypothesis:

Hypothesis 2: Product development and Promotional Strategies enhance the customer satisfaction, and vice versa

As in our case, we are focusing on PTCL, currently they are promoting their products and services to the potential customers. They have signed a contract with franchise (with Islamabad United) of Pakistan Super League - PSL (a big cricket tournament of Pakistan) as main sponsor of Islamabad United in second addition of PSL. They developed a very interesting TVC (Team song) by casting international (such as Shan Watson, Brad Hidden) and local players (Misbah Ul Haq, Muhammad Irfan, Wasim Akram, etc) (Figure 2).

\section{Theoretical framework}

There are two independent variables which act as cause and make an effect on dependent variable. After sales services and product and promotion with customer satisfaction. Let discuss the relationship among dependent and independent:

\section{- Relationship of after sales service with customer satisfaction}

The first independent variable is After-sales and "it is the provision of services, support and spare parts after making an initial sale. This often occurs in the provision of complex machinery which requires regular maintenance such as motor vehicles." By enhancing the after sales services, automatically this will lead to customer satisfaction. So, the relationship among these two variables is positive or direct.

- Relationship of Product and Promotion with customer satisfaction

Product and its promotion is very important in this competitive environment, as there are new competitors like Telenor, Zong, etc. If there will be new products in the market by the company for its customers, it is understandable that there will be high customer satisfaction. So, the relationship between these two variables (independent and dependent variables) is positively or direct.

\section{Research Strategy}

Quantitative research strategy is used as the emphasis in our research is on the evaluation of data by quantifying it. Deductive approach is used in our research for hypothesis testing. The main objective here is to determine the impact of After Sales Services and Product and Promotion on Customer Satisfaction. Non-probability sampling technique such as Convenience sampling is used because we collected data from the respondents based on our convenience.

The research design used is causal research which is used to test whether or not one variable causes another to change, like we were interested in defining After Sales Services and Product and Promotion on Customer Satisfaction. Moreover, research was conducted in noncontrived setting as there was no interference with the normal lecture time. The unit of analysis is individual because we collected data from individual customers of the PTCL.

The instrument for data collection is the self-administered questionnaire. A questionnaire is a data collection instrument in research, "which consists of a series of questions for the purpose of
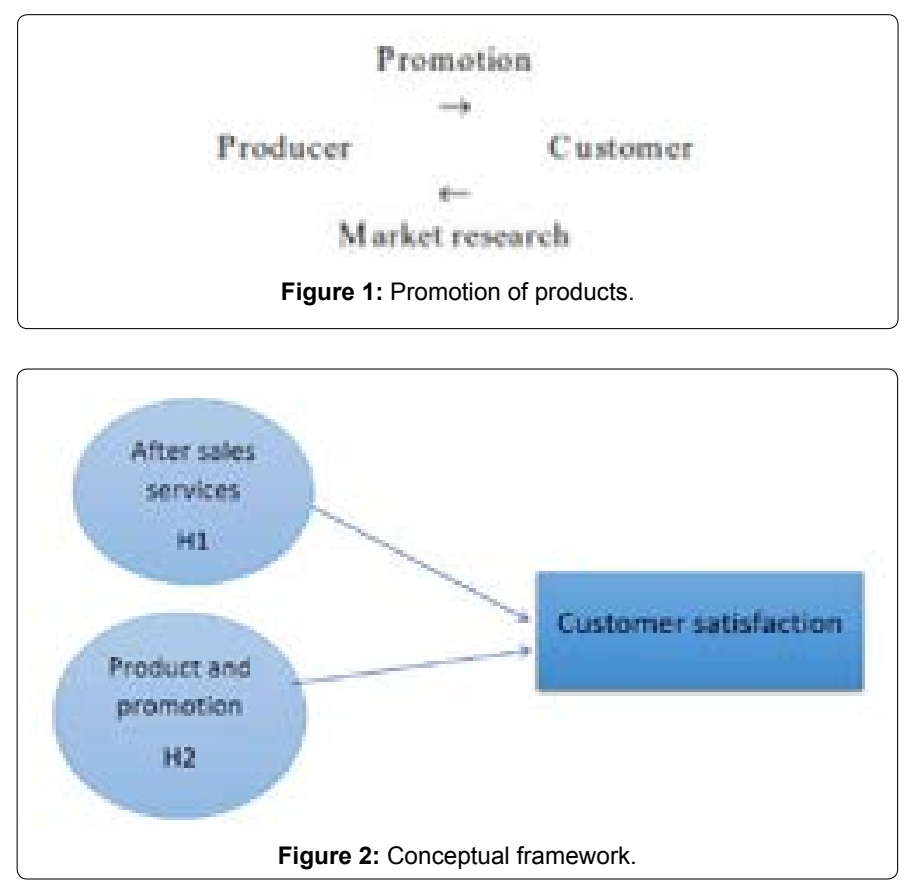
gathering information from respondents" [33]. These questionnaires are structured, and close - Ended. We used this research instrument because it is easy to administer, inexpensive, quick, and easy to analyze. Besides, there is more chance of getting accurate data from large number of respondents in limited time frame, and most importantly any doubts or queries of the respondents could be clarified on the spot. Before distributing questionnaires, we obtained consent from participants for volunteer participation. The questionnaires have been handed over by personal visit. The confidentiality of the responses has been ensured.

We floated 250 questionnaires of our research to the customers of PTCL and we received 221 filled questionnaires, so our sample size is 221, i.e., $\mathrm{n}=221$. A 5-point Likert scale was used to measure our variables e.g. After Sales Services and Product and Promotion on Customer Satisfaction that was " $1=$ strongly disagree, $2=$ disagree, $3=$ neutral, $4=$ agree, $5=$ strongly agree."

\section{Results and Discussion}

In the above Table 1, there are some statistics of our sample size, in which the most considerable values are of Mean, Mode, Standard deviation, range, minimum and maximum. Following are the Pie charts of our research's control variables such as Gender, age, education, and Income in thousands PKR.

In our data set, there are 59 percent males and remaining 41 percent are females who are the customers of the PTCL. This result shows that there is approximately balance across gender in our data we collected from the PTCL's customers (Figure 3).

The second control variable of our research is AGE, this will provide us the little bit about age of users of the PTCL services, including internet. According to our data, there are $35 \%$ customers from the age of $20-30,43 \%$ from the age of $31-40,19 \%$ from the age of $41-50$, and there are only $3 \%$ from the age of above 50 (Figure 4 ).

The third control variable is education, in which there are 56 percent of customers who have graduated educational qualification. And 26\% have post-graduation qualification, 10 percent of customers have doctorate degree and there are 8 percent have intermediate qualifications (Figure 5).

The fourth control variable is income of the customers. There are $10 \%$ who fall in the range of $10-20$, there are 29 percent are fall in the range of 21-30. $17 \%$ of customers have the income range between 41 50 , and there are 12 percent who have income more than 50 thousand salary (Figure 6).

In the below Table 2, all details of control variables are mentioned in the number.

In the above Table 3 of model summary, the most considerable values are $\mathrm{R}$ and $\mathrm{R}$ square. $\mathrm{R}$ square means that the total variance in the dependent variable explained by the independent variable (s) and control variables. In our case, the $\mathrm{R}$ square value is 0.454 or $45.4 \%$. It means that there is 45 percent variance in the customer satisfaction which is our study's dependent variable is explained by the aftersales service and promotion and products which are our research's independent variables and control variables. And R's value is .459 or $45 \%$, which shows correlation in independent variables e.g. The above Table 4 of ANOVA shows the significance results of the any study, in our case we have the significant value is less than .05 which is .000 or $99.99 \%$. On this base, we can conclude that our results are significant.

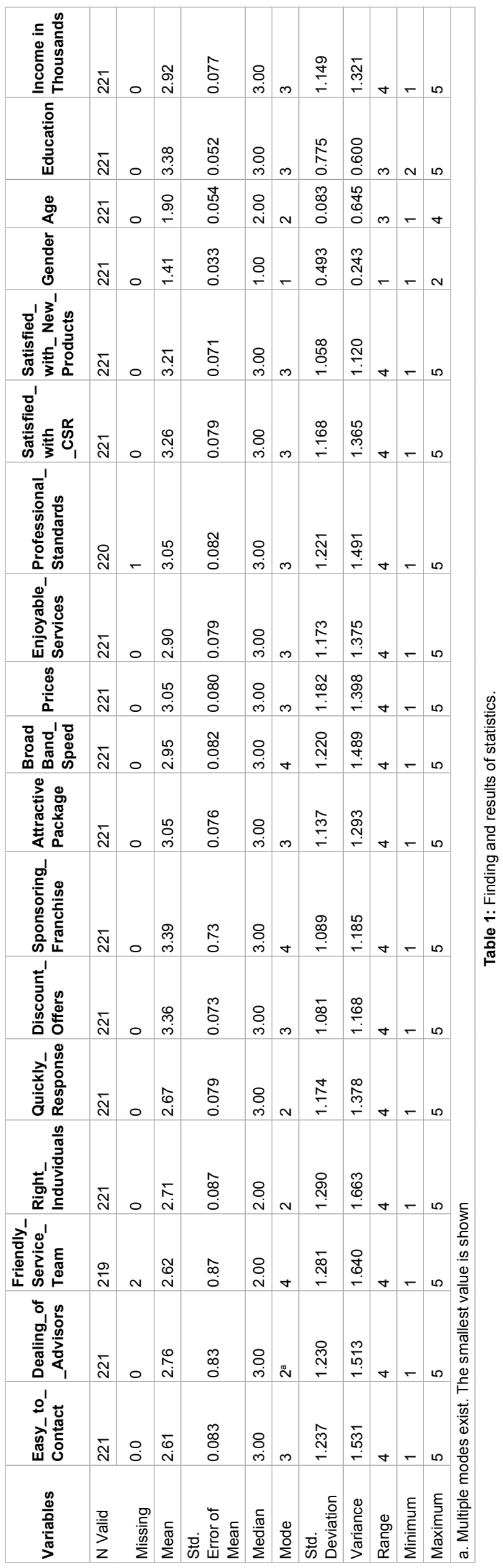



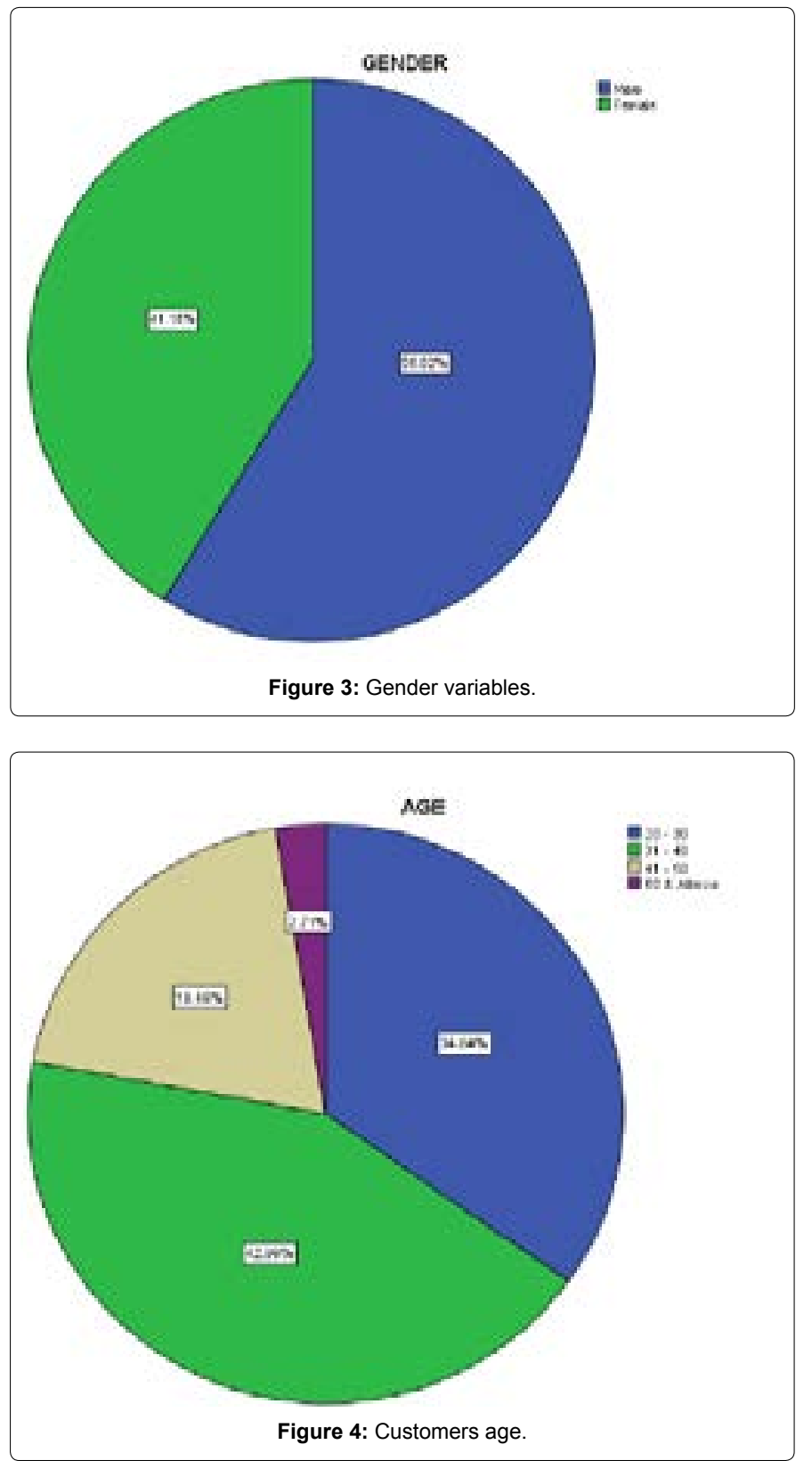

The above Table 5 describes the coefficients and their relations. In this table, we have significant values of our independent values which indicate either hypotheses are accepted or rejected. In our study, we have two independent variables and one dependent variable.

H1: After - Sales services are positively correlated to the customer satisfaction.

Ho: After - Sales services are not correlated to the customer satisfaction.

This is our hypotheses so from the above table we can identify either our hypothesis accepted or not. The significant value of after - sales service is 0.007 , which is less than $0.05(0.004<0.05)$ means the confidence level is $99.3 \%$. The value of $\beta$ (beta) we will take of "standardized Coefficients" because all questions are based on standardized scale which was $1-5$, and it means that after sales service
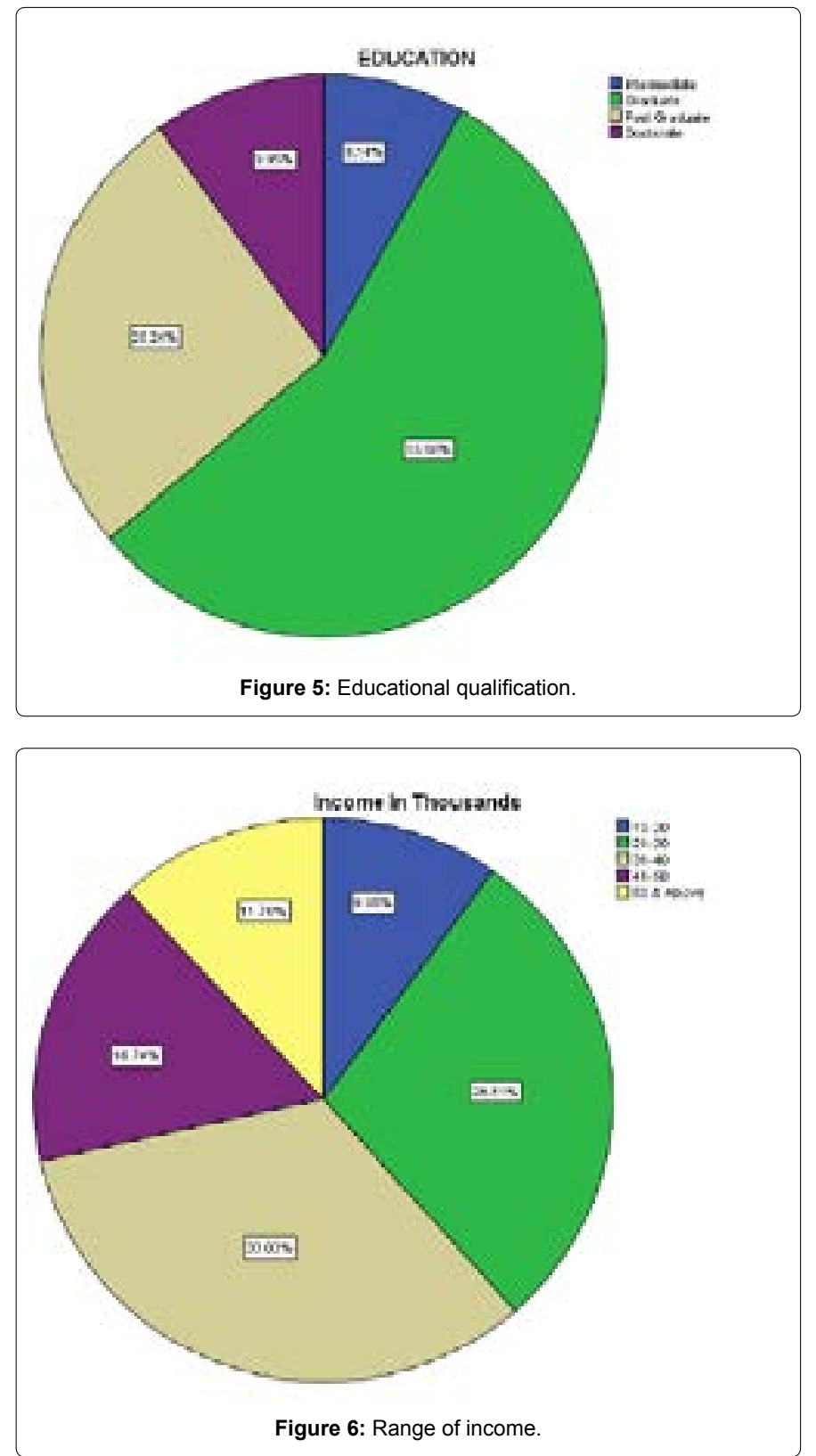

is positively correlated to the customer satisfaction. In other words, we can say that 1 unit increase in after-sales service is likely to increase .182 units of customer satisfaction. Its means if there is good after sales service, it will lead to increase the customer's satisfaction. Hence, we will accept our alternative hypothesis (H1).

H2: Product development and promotional strategies enhance the customer satisfaction, and vice versa.

Ho: Product development and promotional strategies do not affect the customer satisfaction.

The significant value of Product and promotion is .007 which is less than $0.05(.000<0.05)$. The value of $\beta$ (beta) $=.180$ means that product and promotion is positively related to customer customers' satisfaction. In other words, we can say that 1 unit increase in new product and promotion is likely to increase .180 units of customer satisfaction. Hence, we will accept our alternative hypothesis (H1). 
Citation: Nawaz A (2018) Impact of Products, Promotion and after Sale Services on Satisfaction of PTCL's (Pakistan Telecommunication Company Ltd.) Customers. Review Pub Administration Manag 6: 244. doi:10.4172/2315-7844.1000244

Page 6 of 8

\begin{tabular}{|c|c|c|c|c|c|}
\hline \multirow{23}{*}{ Control Variables } & Gender & Frequency & Percent & Valid Percent & Cumulative Percent \\
\hline & Male & 130 & 58.8 & 58.8 & 58.8 \\
\hline & Female & 91 & 41.2 & 41.2 & 100.0 \\
\hline & Total & 221 & 100.0 & 100.0 & 0.0 \\
\hline & Age & Frequency & Percent & Valid Percent & Cumulative Percent \\
\hline & $20-30$ & 77 & 34.8 & 34.8 & 34.8 \\
\hline & $31-40$ & 95 & 43.0 & 43.0 & 77.8 \\
\hline & $41-50$ & 43 & 19.5 & 19.5 & 97.3 \\
\hline & 50 \& Above & 6 & 2.7 & 2.7 & 100.0 \\
\hline & Total & 221 & 100.0 & 100.0 & 0.0 \\
\hline & Education & Frequency & Percent & Valid Percent & Cumulative Percent \\
\hline & Intermediate & 18 & 8.1 & 8.1 & 8.1 \\
\hline & Graduate & 123 & 55.7 & 55.7 & 63.8 \\
\hline & Post Graduate & 58 & 26.2 & 26.2 & 90.0 \\
\hline & Doctorate & 22 & 10.0 & 10.0 & 100.0 \\
\hline & Total & 221 & 100.0 & 100.0 & 0.0 \\
\hline & Income in thousands & Frequency & Percent & Valid Percent & Cumulative Percent \\
\hline & $10-20$ & 22 & 10.0 & 10.0 & 10.0 \\
\hline & $21-30$ & 63 & 28.5 & 28.5 & 38.5 \\
\hline & $31-40$ & 73 & 33.0 & 33.0 & 71.5 \\
\hline & $41-50$ & 37 & 16.7 & 16.7 & 88.2 \\
\hline & $50 \&$ Above & 26 & 11.8 & 11.8 & 100.0 \\
\hline & Total & 221 & 100.0 & 100.0 & 0.0 \\
\hline
\end{tabular}

Table 2: All details of control variables.

\begin{tabular}{|c|c|c|c|c|c|c|c|c|c|}
\hline \multicolumn{10}{|c|}{ ANOVA } \\
\hline \multirow{2}{*}{$\begin{array}{l}\text { Model } \\
\text { summary }\end{array}$} & \multirow{2}{*}{$\mathbf{R}$} & \multirow{2}{*}{ R Square } & \multirow{2}{*}{$\begin{array}{l}\text { Adjusted R } \\
\text { Square }\end{array}$} & \multirow{2}{*}{$\begin{array}{l}\text { Std. Error of the } \\
\text { Estimate }\end{array}$} & \multicolumn{5}{|c|}{ Change statistics } \\
\hline & & & & & R Square Change & F Change & df1 & df2 & Sig. F Change \\
\hline 1 & $0.459^{a}$ & 0.454 & 0.189 & 0.76987 & 0.454 & 9.412 & 6 & 211 & 0.000 \\
\hline
\end{tabular}

Table 3: Considerable values and statistics.

\begin{tabular}{|c|c|c|c|c|c|c|}
\hline Model & & Sum of Squares & df & Mean Square & $\mathbf{F}$ & Sig. \\
\hline \multirow{3}{*}{1} & Regression & 33.470 & 6 & 5.578 & 9.412 & $0.000^{b}$ \\
\hline & Residual & 125.060 & 211 & 0.593 & - & -- \\
\hline & Total & 158.530 & 217 & - & - & - \\
\hline
\end{tabular}

a: Dependent variable: Customer_satisfaction

b: Predictors: (Constant), Income in Thousands, Gender, Product_and_Promotion, Age, After_Sales_Services_Education

Table 4: Significance results of ANOVA.

\begin{tabular}{|c|c|c|c|c|c|c|}
\hline \multicolumn{7}{|c|}{ Coefficients } \\
\hline \multirow{2}{*}{\multicolumn{2}{|c|}{ Model Summary }} & Unstandardized & Coefficients & $\begin{array}{l}\text { Standardized } \\
\text { Coefficients }\end{array}$ & \multirow[t]{2}{*}{$\mathbf{t}$} & \multirow[t]{2}{*}{ Sig. } \\
\hline & & B & Std. Error & Beta & & \\
\hline \multirow{7}{*}{1} & (Constant) & 1.785 & 0.444 & & 4.025 & 0.000 \\
\hline & After_Sales_Services & 0.169 & 0.062 & 0.182 & 2.737 & 0.007 \\
\hline & Product_and_Promotion & 0.236 & 0.086 & 0.180 & 2.726 & 0.007 \\
\hline & Gender & 0.428 & 0.108 & 0.248 & 3.975 & 0.000 \\
\hline & Age & -0.024 & 0.068 & -0.022 & -0.350 & 0.727 \\
\hline & Education & -0.160 & 0.080 & -0.146 & -2.015 & 0.045 \\
\hline & Income in Thousands & 0.034 & 0.051 & 0.046 & 0.657 & 0.512 \\
\hline
\end{tabular}

Table 5: Unstandardized and standardized coefficients values.

\section{Analysis of control variables}

In this analysis, we will take the beta value of unstandardized coefficients' value because these control variables are not standardized, all these have different number of categories.
- Gender: Analysis shows that males are more associated with customer Satisfaction, as you can see in the above Table $2(\mathrm{~b}=-$ $0.428, \mathrm{p}=0.000$, which is less than 0.05 ).

- Age: The result shows that customers who have the age 20- 
31 (young) are less associated than others, such as mature and elders, because the beta value is zero and results are not significant $(b=-0.024, p=0.727$, which is greater than 0.05$)$.

- Education: According to the analysis, education is negatively correlated with customer satisfaction, and significant value is less than 0.05 , it means that one unit increases in the education will likely to decreases the -.160 units in customer satisfaction $(b=-0.160, p=0.045)$.

- Income: According to the analysis, income does not have any effect on customer satisfaction $(\mathrm{b}=0.034, \mathrm{p}=0.512)$.

\section{Discussion}

As we mentioned in the introduction, PTCL is a Government owned company. In this era of competition, it is very tough time not only for private firms but also for the public firms. Results showed that the continuous improvement in products offered by PTCL enhance the satisfaction level of the customers. Few years ago, PTCL introduced broadband internet services for their users, which has been observed a fruitful strategy to remain in the market by competing its other competitors such as Zong, Jazz, Warid, and Telenor - other telecommunication services providers.

This study revealed that there is a strong casual relation between Product and promotion on customer satisfaction. Mackenzie et al. [21] compared four theoretical models of advertising and showed that attitudes toward ads have direct effects on brand attitudes and subsequently on purchase intentions. Consumer's affective and cognitive reactions to these messages presumably determine the relation between ad evaluations and brand evaluations. Brand beliefs [18] and feelings $[19,20]$ are formed through advertising. An important question arises here, why is it rational for the suppliers/manufacturers and retailers to offer Promotion? To answer this question, Blattberg and Neslin [27] offer a concise categorization of the economic explanations that have been proposed in the literature. They added to this, "One set of arguments is based on differential costs of search and information processing, inventory-carrying, and time, across consumers."

Second independent variable, after sales services. Service has been rightly treated as one reliable vehicle for gaining sustainable competitive advantage, which means that service quality aspects possess a substantial strategic role for companies. This does not happen only in the pure service sectors, but also in many others where service is a considerable part of the augmented product. Indeed, the concept of "service quality" can be used to all sectors, since practically everywhere the total product-offering is a mixture comprised by a tangible and an intangible part.

The positive perceptions and attitudes of the target customers towards the quality-elements offered by the firm, leads to both attraction of new customers thanks to word-of-mouth (WOM) communication and recommendations of the existing customers, as well as to enhancement of the relationship of the company with its current customers by making them more loyal and committed. In other words, when referring to overall service quality perceptions, it is noticed that a substantial body of the literature [12] is in line with Zeithaml et al. [13] findings, claiming that overall service quality perceptions influence WOM communication, recommendations, as well as Loyalty. In this context, customer satisfaction has been the subject of a substantial body of literature [14] because of its influence on customer behavioral intentions and attitudes [15,16]. Regarding behavioral intentions, Zeithaml et al. [13] suggest that favorable behavioral intentions are mostly in the form of customers' referrals and recommendations, customers' willingness for re-purchasing as well as customers' willingness to spend more money with the particular company or to pay more for the products of this company.

\section{Limitations and Recommendations}

- The sample size was kept at 221 which might make it difficult to generalize the results. A larger sample size would most probably enhance the insight into the dynamics of the relation of customer's satisfaction with after sales services and product and promotion.

- Due to time constraint, the theoretical model was kept very simple. Keeping in view the dynamics of Pakistani market environment, it is suggested that some mediators may be added in the model so that a more concrete understanding of the phenomenon can be established.

- Companies can enhance their quality by getting a regular feedback from their customers and organizations should adopt new methods of enhance a customer satisfaction.

\section{Conclusion}

This research was primarily intended to get an insight into and enhance our understanding regarding the impact of after sales service and promotion and products on customer satisfaction. After sales service and promotion and products were found to have a positive impact on the customer satisfaction. Survey questionnaire were administered in customers of PTCL. The sample size of the research was 221 . Both the research hypothesis proposed were accepted as per the research findings.

\section{References}

1. Fazlzadeh A, Bagherzadeh F, Mohamadi $P$ (2011) How after-sales service quality dimensions affect customer satisfaction. Afr J Bus Manage 5: 76587664.

2. Agnihothri S, Sivasubramaniam N, Simmons D (2002) Leveraging technology to improve field service. Int J Ser Ind Manage 13: 47-68.

3. Goffin K, New C (2001) Customer support and new product development-An exploratory study. Int Oper Prod Manage 21: 275-301.

4. Giese JL, Cote JA (2000) Defining consumer satisfaction. Acad Market Sc Rev 1: 1-27.

5. McDougall GH, Levesque T (2000) Customer satisfaction with services: Putting perceived value into the equation. J Serv Market 14: 392-410

6. McQuitty, S, Finn A, Wiley JB (2000) Systematically varying consume satisfaction and its implications for product choice. Acad Market Sci Rev 10 : $1-18$.

7. Erevelles S, Leavitt C (1992) A comparison of current models of consume satisfaction/dissatisfaction. J Consum Satis Dissatis Compl Behav 5: 104-114.

8. Lele MM, Karmarkar US (1983) Good product support is smart marketing. Harvard Bus Rev 61: 124-132.

9. Loomba AP (1998) Product distribution and service support strategy linkages: An empirical validation. Int J Phys Distrib Logist Manage 28: 143-161.

10. Oliva R, Kallenberg R (2003) Managing the transition from products to services. Int J Serv Ind Manage 14: 160-172.

11. Gaiardelli P, Saccani N, Songini L (2007) Performance measurement of the after-sales service network-Evidence from the automotive industry. Comp Ind 58: 698-708.

12. Boulding W, Kalra A, Staelin R, ZeithamI VA (1993) A dynamic process mode of service quality: from expectations to behavioral intentions. J Market Res 30 7-27. 
Citation: Nawaz A (2018) Impact of Products, Promotion and after Sale Services on Satisfaction of PTCL's (Pakistan Telecommunication Company Ltd.) Customers. Review Pub Administration Manag 6: 244. doi:10.4172/2315-7844.1000244

Page 8 of 8

13. Zeithaml VA, Berry LL, Parasuraman A (1996) The behavioral consequences of service quality. J Market 60: 31-46.

14. Rust RT, Oliver RW (1994) The death of advertising. J Advertising 23: 71-77.

15. Anderson EW, Sullivan MW (1993) The antecedents and consequences of customer satisfaction for firms. Market Sci 12: 125-143.

16. Cronin JJ, Taylor SA (1992) Measuring service quality: A reexamination and extension. J Market 56: 55-68.

17. Keller KL (2003) Brand synthesis: The multidimensionality of brand knowledge. J Consum Res 29: 595-600.

18. MacKenzie SB, Lutz RJ, Belch GE (1986) The role of attitude toward the ad as a mediator of advertising effectiveness: A test of competing explanations. J Market Res 23: 130-143

19. Olney TJ, Holbrook MB, Batra R (1991) Consumer responses to advertising: The effects of ad content, emotions, and attitude toward the ad on viewing time. J Consum Res 17: 440-453.

20. Park CW, Jaworski BJ, MacInnis DJ (1986) Strategic brand concept-Image management. J Market 50: 135-145

21. Jarvis CB, MacKenzie SB, Podsakoff PM (2003) A critical review of construct indicators and measurement model misspecification in marketing and consumer research. J Consum Res 30: 199-218.

22. Barich $H$, Kotler $P$ (1991) A framework for marketing image management. Sloan Manage Rev 32: 94-104.

23. Dowling GR (1986) Managing your corporate images. Ind Market Manage 15: 109-115.
24. Keller KL, Aaker DA (1992) The effects of sequential introduction of brand extensions. J Market Res 29: 35-50.

25. Biehal GJ, Sheinin DA (1998) Managing the brand in a corporate advertising environment: A decision-making framework for brand managers. J Advert 27: 99-110.

26. Rowley J (1998) Promotion and marketing communications in the information marketplace. Library Rev 47: 383-387.

27. Blattberg RC, Neslin SA (1990) Sales promotion: Concepts, methods, and strategies. Englewood Cliffs, NJ: Prentice Hall 349-350.

28. Varian HR (1980) A model of sales. Ame Econ c Rev 70: 651-659.

29. Blattberg RC, Eppen GD, Lieberman J (1981) A theoretical and empirical evaluation of price deals for consumer nondurables. J Market 45: 116-129.

30. Dibb S, Simkin L (1994) Implementation problems in industrial marke segmentation. Ind Market Manage 23: 55-63.

31. Yoo B, Donthu N, Lee S (2000) An examination of selected marketing mix elements and brand equity. J Acad Market Sci 28: 195-211.

32. Huang R, Sarigöllü E (2014) How brand awareness relates to market outcome, brand equity, and the marketing mix. In fashion branding and consumer behaviors. J Bus Res 65: 92-99.

33. Gault RH (1907) A history of the questionnaire method of research in psychology. The Pedagogical Seminary 14: 366-383. 